\title{
第一届波蘭科學會義的理論基礎
}

\section{克拉索夫斯卡耶著 張國光譯}

第一届波蘭科學會議工作的結果，和它黨求

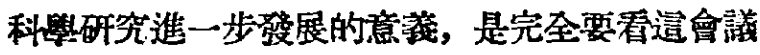
工作是否是符合了它的理想和內容。

以今日波䉒科學的情形來說，它的成就和社 會一政治進展的速度是䫏得不均衡的。科學還浔 有能與流會主䔐建設的發展亚駕齊驅，它沿有配 合新社會的需要，這在波蘭科學未来理想的過程 中是必須加速推動的。

在這樣的情况下，波蘭科學會議，動員波蔽全

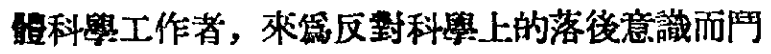
争，來第緊密聯慗波闻人民的理想以及完成六年 計割而网争。经求新的科學而网争，是必須在廣泛 和熱烈的科學討論中，在根據馬列主義理論基礎 的無情的批判中進行的。

科䊆會議的篊借工作是具有無限的意義, 因 忿道使科學工作者具有雨補科學批判領域內的重 大的缺陷的可能, 紏正了許多徧見和自流偏向的 錯誤。這更使科學工作者能從人民民主國管需婆 的觀點上，特别是從六年計港的原則上，來發展科 學。

在科學界一切因循,杲滞和蒙昧主義的現象，

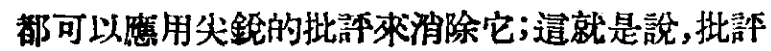
須要針對一定的人物，一定的事件以及針對某一 科藇的傾向所表現的方法諭的問題。

一種有創造性的批評，是揭示了科學發展的 遗最。

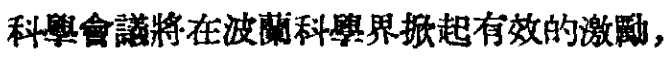
加强磪信波等科學進一步的搏展是不可能不接受 新的、專門的科學理諭，並在波蘭科學工作者之

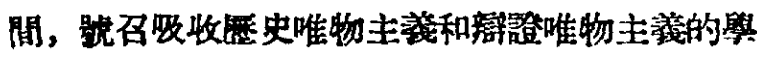

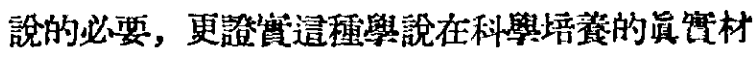
料中雇用的成績。

在科學工作者之間，理性感念的增長，將促進 對世界的問題一般討論的開始，特别是對科學分 門别類的條件,和它在社會上的作用，以及各别的 科學理諭與唯物諭及觀念論的篎係。

在追一方面，學習先進的蘇聯科學，將對我們

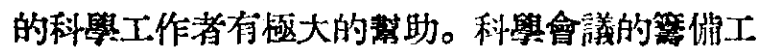
作將防止我們的科學不受目前世界向的影響。 這亚不是說我們是要從世界科學的成就上切断了 關係,亦不是說我們要抹殺它的功績,或是證留對 它相置不顧。

解決世界上娤難問題的知識和研究工作的技 街方法,必須聯繫到發展自己國家科學的项任; 於從事科舉工作的選擇，㮣當符合人民生活墢展 的超向和需要。

要克服在科舉領域的世界觀是可能的，的区奖

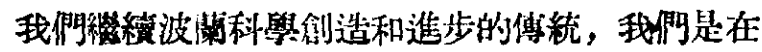
理諭與望践就一的原則中從事科學工作。這一原 則是得到了一件事卧有力的反胦，因复科學會議 的籍備工作正是在波简六年建設㣔劃中的第一年

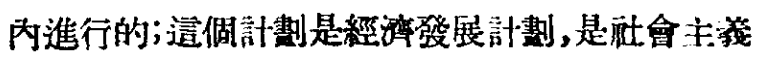
的集石基礎。

波䇲共和國期望科學工作者計劃與人民生活 發展趣向有關係的科學工作，人民國家要保證他 們在工作上一切的便利。

（臎自波闌科學月利 ‘現代㤁潮’ 第 8-9 期

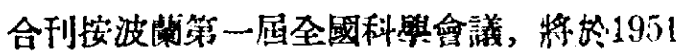
年淟行，此文是作者在開會以前竄的） 